\title{
Global Migration Challenges, International Organizations and European Politics
}

\author{
L.E. llikova ${ }^{1 *}$ \\ Elena A. Venidiktova ${ }^{1}$ \\ ${ }^{1}$ Kazan Federal University, Kazan, Tatarstan, Russia \\ *Corresponding Author
}

Doi: 10.36941/ajis-2019-0051

\begin{abstract}
Migration is a global issue. The period 2015-2016 is associated with the migration crisis, which touched several regions of the world at once and made and continues to make an impact on global world processes. The growth of migration flows leads to the need to understand the causes and the consequences of migration, including global migration trends. The following world migration trends and causes are considered: the growth of world population, overpopulation, climate change, demographic processes, the reduction of natural resources, and unresolved armed conflicts. The global problems of migration cannot be solved by the efforts of individual countries. An effective and coordinated cooperation of both state and supranational entities, such as the European Union, is necessary.
\end{abstract}

Keywords: Migration, migration crisis, international organizations, Africa, population growth, European politics, far-right parties

\section{Introduction}

The Cold War ended more than a quarter century ago, which almost put the world on the brink of destruction. The confrontation between the two blocs and the arms race became the problems that influenced the whole world and determined world development. Nuclear disarmament was necessary and this issue was resolved with the participation of all the major players in world politics. Since then, many events have taken place that have had a tremendous impact on the political landscape and on world development. This is the collapse of the USSR, the expansion of the NATO bloc, the expansion of the EU, and the world conflicts in the Middle East (Novak, 2019; Colucci, 2019; Ripoll Servent \& Trauner, 2014; Heijer et al., 2016; https://www.unhcr.org; http://www.un.org).

Nowadays, the world faces a global problem again - the problem of migration. Migration is a global issue. The period of $2015-2016$ is associated with the migration crisis, which touched several regions of the world at once and has had and continues to have an impact on global world processes. According to United Nations High Commissioner for Refugees ${ }^{1}$, there were 59.5 million IDPs, 19.5 million of refugees and another 10 million stateless people in the world (2015). Of these, every second (53\%) came from three main countries in 2015: Somalia (1.1 million), Afghanistan (2.59 million), and Syria (3.88 million). At that, the crises that started back then remained unchanged. The flow of refugees from Afghanistan began almost 40 years ago, but about two million of Afghan refugees are still stationed in the Islamic republics of Iran and Pakistan, and hundreds more thousands are on the run (http://www.internal-displacement.org; https://www.zeit.de). 


\section{Methodology}

In this work, they used the methods of statistical data analysis, comparative analysis, the methodology of social network analysis was used to analyze the open data of the social network Facebook, as well as the methodology of discourse analysis as a set of analytical methods for text and statement interpretation as speech activity of people carried out in specific socio-political circumstances and cultural-historical conditions.

\section{Results and Discussion}

According to the UN, by the end of 2017 there were 71.4 million refugees, internally displaced persons, asylum seekers, etc. As of the end of 2017, about 72 million people around the world are asylum seekers, refugees, internally displaced persons and stateless persons cared by UNHCR. Millions of people were displaced throughout the year, fleeing war, violence and persecution in countries including such countries as the Central African Republic, Democratic Republic of the Congo (DRC), Iraq, Myanmar, South Sudan and the Syrian Arab Republic.

According to Vincent Kochetel, UNHCR's Special Envoy in the Central Mediterranean region: "The evacuation of refugees can only be the part of the broader asylum process - management efforts to address the complex movements of migrants and refugees who embark on a dangerous journey across the Sahara and the Mediterranean Sea."1

The growth of migration flows leads to the need to understand the causes and consequences of migration, including global migration trends. Thus, researchers note the difficulties of intraEuropean politics (Potemkina \& Potemkina, 2015; Skleparis, 2018; Campesi, 2018), the lack of solidarity in foreign policy, in particular the European Union (Lang, 2013), the presence of unresolved armed conflicts, financial and economic crises (Trauner, 2016; Maricut-Akbik, 2019), and the causes of migration are associated with climate change, demographic processes, and the reduction of natural resources very often.

Let us consider global migration trends and causes in more detail. The first and main reason pushing the masses of people to relocate regardless of political factors is the growth of world population, overpopulation.

In 1950, five years after the founding of the United Nations, the world population was about 2.6 billion. In 1987, it reached 5 billion people, and 6 billion people in 1999. As of October 2011, the global population was 7 billion people. This milestone in the history of mankind has been marked by the global campaign "Seven Billion Actions." By 2017, the population was already 7.5 billion people.

The main increase of population is conditioned by the African continent. Africa demonstrated the highest population growth rate in 2010-2015, respectively, the largest percentage of young people is also in Africa, the increase in fertility is also expected in Africa, according to various estimates, the increase to 0.9 billion people is expected in the African continent alone by 2050 .

At the same time, the opposite trend is in Europe - the reduction and aging of the population. According to the UN, the world population decline is expected during the period of 2015-2050 in 48 countries and regions. In several countries, including Bulgaria, Bosnia and Herzegovina, Hungary, Latvia, Lithuania, the Republic of Moldova, Serbia, Ukraine, Croatia and Japan, the population will be decreased by more than $15 \%$ by 2050 . In 2017, the planet population at the age of 60 and over reached 962 million, accounting for 13 percent of the global population. The number of elderly people is growing at the rate of three percent per year. Nowadays, the largest number of people at the age of 60 and over live in Europe (25 percent). Aging is accelerating in other regions of the world. By 2050, this group is expected to comprise a quarter of the population of all regions except Africa. The global elderly population will reach approximately 1.4 billion by $2030,2.1$ billion by 2050 , and 3.1 billion by 2100 .

According to UN forecasts, the number of people on the planet at the age of 80 and over will triple from 137 million in 2017 to 425 million in 2050. By 2100, this figure will be 909 million, which is almost seven times more than in 2017.

That is, it can be assumed that in some regions of the world population will be replaced, for example, young people from Africa will move to Europe, in particular. We can see migration 
problems: this is the growing popularity of right-wing parties, anti-immigration sentiments, and the clashes between different groups of refugees and local residents.

Along with the growth of the world population, there is the reduction in food and water resources. In this regard there is the restriction of access to resources and this is the second global cause of migration.

According to the UN, more than 40 percent of the world population suffers from water shortages and this figure is constantly growing. According to experts, 783 million inhabitants of the planet have no access to clean water and more than 1.7 billion people living in river basins need additional sources of fresh water.

The number of people suffering from chronic malnutrition has been steadily increasing since 2014 and reached 815 million in 2017 . World food demand is growing steadily amid population increase, record crops, rising incomes and a growing variety of diets.

Such conditions will also entail the increase of migratory flows of people from disadvantaged areas to more stable areas. And this leads to the third global cause of mass migration - climate change.

Climate change is one of the major modern challenges. For example, the unpredictability of weather conditions, which threatens food production, sea level rise, which increases the risk of natural disasters, are the consequences of climate change and are global in nature and unprecedented by scope. Natural disasters, droughts and floods cause people to leave their homes and new waves of migration begin.

The difference in welfare levels in different countries also provokes new migratory flows. According to the Center for Monitoring Internal Displacement1, armed conflicts and natural disasters forced almost 31 million people to become refugees within their countries in 2016, more than 18 million provide new internal displacements related to disasters recorded in 135 countries during 2017. The effects of climate change and natural disasters exacerbate fragile situations in fragile regions. In 2017, UNHCR priority is normative decisions, promoting coherence policies, and developing support tools for national responses, including the areas of climate change, disaster risk reduction, human rights, and planned relocation. The UNHCR Report on Climate Change, Natural Disasters and Migration emphasized the need for a system-wide approach to struggle climate change and natural disasters related to migration. In April 2017, UNHCR issued a specific legal consultation entitled "Legal considerations regarding the protection of refugees and people fleeing from conflict and hunger." This confirmed the relevance and analysis of the situation.

Another reason for migration that has a global impact on international processes is unresolved armed conflicts. Armed conflicts, "frozen conflicts" and violence in the region lead to refugee flows. According to the UN data, in addition to the currently known case of Syria, the number of conflicts has now decreased as compared to the 1990-ies, but often the causes of conflicts have not been eliminated and the conflicts can only be transferred to a frozen state. Thus, the Democratic Republic of the Congo, Darfur and South Sudan experience the second or even the third wave of conflict. In 2016, new internal displacements made almost 7 million as the result of conflicts and violence. SubSaharan Africa has overtaken the Middle East as the most affected region after violent clashes in the provinces of North Kivu, South Kivu and Kasai in the Democratic Republic of the Congo which provided almost 1 million of new relocations. Significant population movements continued in the Middle East, and about two million of new movements occurred during 2016 in Syria, Iraq and Yemen. By the end of 2017-2918, there were 10 countries that hosted the most refugees: Turkey, Lebanon, Ethiopia, Bangladesh, Jordan, Pakistan, Iran, Sudan, Uganda and Germany.

All internal movements cease to be internal when migration flows rush into a stable and prosperous European Union. In turn, migration as a phenomenon has a huge impact on all aspects of public life in the European Union.

Let us examine Germany as the most striking case that influenced the relations within the EU. Since its founding in 1953, about 5.6 million people in Germany have sought for refuge. The number of asylum applications at the Federal Bureau for Migration and Refugees is subject to fluctuations, which are the expression of global refugee movement development. In 2015, an unprecedented number of asylum seekers arrived in Germany. The number registered seekers made about 890,000 . Thus, the highest level was registered in Germany with 745,545 asylum 
applications in 2016. The number of applications fell to 222,683 in 2017. Since 2003 the tasks of the Federal Office in the field of asylum and refugee protection include the organization of particularly vulnerable refugee perception through the resettlement process. The intake quota has steadily increased from initially 300 vulnerable people a year to 1,600 in 2016 and 2017. Germany promised the EU to accept 10,200 refugee migrants in 2018 and 2019. According to the resettlement procedure in 2015-2017, more than 10,000 of predominantly Syrian refugees from Greece and Italy were distributed to Germany (Italian Ministry of Internal Affairs operation restricting the entry and placement of illegal migrants and refugees in Italy).

Returning to the European migration crisis of $2015-2016 \mathrm{~m}$, the migration flow was a real test of strength for the European Union, when many unresolved problems of a single European policy were discovered. There is no agreed policy on migration problem solution, and this became clear when the flow of migrants increased sharply (the same 890,000 people in Germany during 2015, for example). Different EU countries, having failed to reach an agreement, began to solve the problem in their own way. So, Germany still maintains the status of a country open to migrants and refugees, despite the split within the CDU-CSU and the scandal. Hungary and the Visegrad group as a whole took a sharply negative position with regard to migrants, the Dublin Regulation, and the EU migration policy as a whole. The entire Visegrad group ignored the emergency EU summit in June 2018.

Hungary decided not to accept refugees in 2015 (mainly the refugees from African countries and the Arab East), held the referendum on whether to accept refugees on EU quotas and, although the referendum was not recognized, $98 \%$ of voted refused to accept migrants and refugees, which was used by the Hungarian government to reinforce its anti-immigration position in negotiations with official Brussels. In order to solve the problem of illegal entry into Hungary, it was decided to build a wall on the border with Serbia. Besides, the law was passed at the national level that all arriving migrants and refugees will be placed in special detention premises. Hungary clearly opposes the admission of foreign cultural migrants. The Prime Minister Viktor Orban has been very consistent and tough on this issue.

Germany is an example of the opposite position, when, on the contrary, the country was ready to let in migrants, and the German Chancellor Angela Merkel said the following in 2015: "EU is a large union which can accept a certain number of these unfortunates. We can handle it!" And Germany still admits, providing asylum, providing temporary housing and pursuing the policy of openness. At that, certain changes have ripened and Horst Seehofer, as the Minister of Internal Affairs in 2018, insisted on the policy of migrant and refugee reception restriction, on their placement in "anchor centers", as well as on strict identification procedures to avoid the accept of economic migrants instead of refugees and asylum seekers. Sweden is also inclined to accept more migrants, despite the fact that, according to various estimates, from $17 \%$ to $25 \%$ of residents of non-Swedish origin live in the country, and the right-wing party "Swedish Democrats" is gaining popularity gradually. The Austrian Chancellor Sebastian Kurtz changed the rhetoric of migrant integration, announcing that it would be wise to build refugee camps outside the EU. France took a controversial position - officially it supports the EU course in migration policy, but at the same time in the summer of 2017, the Ministry of Internal Affairs closed the ports with an internal circular, virtually refusing to accept the ships with refugees, thus putting Italy in jeopardy. Italy, left alone with the problem of migration, especially illegal, tries different solutions: the first is restrictive, with which the right-wing League went to the polls. This option was embodied in the operation of the Ministry of Internal Affairs "Finita la pacchia!"1. This option caused a sharp aggravation of relations within the EU, the convening of an emergency EU summit in June, but did not lead to any decision. Further, Italy proposed the options for refugee camp establishment in Libya, since there are large flows of immigrants from there and from Tunisia. This is a difficult option in Libya, since the situation in the country is unstable, in fact, the authorities do not control the situation. And there is a new proposal from Italy: the preparation of an agreement on cooperation with Nigeria in order to facilitate the creation of the necessary infrastructure within the country, while the amount of 8.5 euros per day will be paid. That is, it is about shifting the focus of attention and assistance to refugees and asylum seekers "in the field", that is, to the African continent. Subsequently, this practice is planned to be extended to other African countries of migrant origin.

At the moment, the consequences of the migration crisis in the EU have not been resolved. 
They did not achieve the unity in the formation and implementation of a single migration policy of the European Union, and the topic of migration itself as the destabilization and disintegration factor of the EU.

\section{Conclusions}

It is impossible to solve global problems through the efforts of individual countries; an effective cooperation is necessary. It is unacceptable to destroy countries and change regimes in individual countries for the sake of economic and political interests, and it is unacceptable to support terrorist organizations for the political purposes of individual countries.

The destruction of even "distant countries" destabilizes the situation in the entire region, violates the status quo and affects countries that seem to be unrelated to the conflict (Syria affects Turkey, then the eventual impact extends to Germany and even Sweden). Global problems can only be solved with the participation of all actors involved. The policy "Not in my backyard" is not justified in the modern world.

\section{Acknowledgements}

The work is performed according to the Russian Government Program of Competitive Growth of Kazan Federal University.

\section{References}

Campesi, G. (2018). Seeking asylum in times of crisis: Reception, confinement, and detention at europe's southern border. Refugee Survey Quarterly, 37(1), 44-70.

Colucci, M. (2019). Foreign immigration to Italy: crisis and the transformation of flows. Journal of Modern Italian Studies, 24(3), 427-440.

Heijer, M. D., Rijpma, J., \& Spijkerboer, T. (2016). Coercion, prohibition, and great expectations: The continuing failure of the Common European Asylum System. Common Market Law Review, 53(3), 607-642.

http://www.internal-displacement.org/global-report/grid2017/

http://www.internal-displacement.org/global-report/grid2017/

http://www.internal-displacement.org/global-report/grid2017/

http://www.internal-displacement.org/global-report/grid2017/

http://www.un.org/ru/sections/issues-depth/ageing/index.html

http://www.un.org/ru/sections/issues-depth/food/index.html

http://www.un.org/ru/sections/issues-depth/population/index.html

https://www.unhcr.org/globaltrends2018/

https://www.zeit.de/2015/38/angela-merkel-fluechtlinge-krisenkanzlerin/seite-4

Italian Ministry of Internal Affairs operation restricting the entry and placement of illegal migrants and refugees in Italy

Lang, I. G. (2013). Is there solidarity on asylum and migration in the EU?. Croatian Yearbook of European Law and Policy, 9(1), 1-14.

Maricut-Akbik, A. (2019). EU politicization beyond the Euro crisis: immigration crises and the politicization of free movement of people. Comparative European Politics , 17(3), 380-396.

Novak, P. (2019). The neoliberal location of asylum. Political Geography, 70, 1-13.

Potemkina, O., \& Potemkina, O. Ju. (2015). Migracionnye Problemy v Evrope i Puti Ih Reshenija. Kondrat'eva N. B. (otv. redaktor), M.: Doklady Instituta Evropy, 315

Ripoll Servent, A., \& Trauner, F. (2014). Do supranational EU institutions make a difference? EU asylum law before and after 'communitarization'. Journal of European Public Policy, 21(8), 1142-1162.

Skleparis, D. (2018). A Europe without Walls, without Fences, without Borders': A Desecuritisation of Migration Doomed to Fail. Political Studies, 66(4), 985-1001.

The Office of the United Nations High Commissioner for Refugees https://www.unhcr.org/ru/\%d0\%bc\%d0\%b0 \%d0\%bd\%d0\%b4\%d0\%b0\%d1\%82-\%d0\%b8-\%d1\%86\%d0\%b5\%d0\%bb\%d0\%b8-\%d0\%b0\%d0\%b3\%d0 $\% \mathrm{~b} 5 \% \mathrm{~d} 0 \% \mathrm{bd} \% \mathrm{~d} 1 \% 82 \% \mathrm{~d} 1 \% 81 \% \mathrm{~d} 1 \% 82 \% \mathrm{~d} 0 \% \mathrm{~b} 2 \% \mathrm{~d} 0 \% \mathrm{~b} 0$

Trauner, F. (2016). Asylum policy: the EU's 'crises' and the looming policy regime failure. Journal of European Integration, 38(3), 311-325. 